\title{
PERBEDAAN SOIL TRANSMITTED HELMINTHS (STH) PADA SAYURAN DI PASAR TRADISIONAL DAN PASAR MODERN
}

\author{
Rian Primadi Jasman1, Rahmadani Sitepu2, Selly Oktaria2
}

1Mahasiswa Magister Fakultas Kesehatan Masyarakat, Universitas Sumatera Utara 2Dosen Fakultas Kedokteran, Universitas Islam Sumatera Utara

\begin{abstract}
Differences in Transmitted Helminths (STH) Soil in Vegetables in Traditional and Modern Markets. Soil Transmitted Helmiths (STH) infections are still a problem in many regions of the world, there are more than 1.5 billion people or $2.4 \%$ of the world's population infected by helminthiasis transmitted through land. STH distribution in Indonesia covers all islands in Indonesia, where the highest prevalence is found in Papua and North Sumatra with a prevalence between $50 \%$ to $80 \%$. One source of transmission is water and mud which is used in the cultivation of vegetables. Worm contamination can occur mainly in vegetables that spread on the surface of the soil or elevation close to the ground. The research that will be conducted is analytic research with cross sectional research design. The research sample consisted of 50 vegetables consisting of lettuce, leeks, cabbage, spinach, and mustard as many as 50 samples taken from traditional markets and modern markets in Medan. From the results of this study it was found that the highest positive STH results in traditional markets were 10 vegetables or $(40 \%)$ and the lowest positive STH results in the modern market were 3 vegetables or $(25 \%)$. Based on the results of this study it could be concluded that there were differences in STH from vegetables sold in traditional markets with modern markets as evidenced by the $p$ value in this comparison is $p=0.035$, so there is a difference between Soil Transmitted Helmints contamination between traditional markets and modern markets.
\end{abstract}

\section{Keywords: Soil Transmitted Helminths, Traditional Market, Modern Market}

\begin{abstract}
Abstrak:Perbedaan Soil Transmitted Helminths (STH) pada Sayuran di Pasar Tradisional dan Pasar Modern. Infeksi Soil Transmitted Helmiths (STH) masih merupakan masalah di banyak daerah di dunia, terdapat lebih dari 1,5 milyar orang atau $2,4 \%$ dari populasi dunia terinfeksi kecacingan yang ditularkan melalui tanah.Distribusi STH di Indonesia mencakup seluruh pulau yang ada di Indonesia, dimana prevalensi tertinggi terdapat di Papua dan Sumatera Utara dengan prevalensi antara $50 \%$ hingga $80 \%$. Salah satu sumber penularannya adalah air dan lumpur yang digunakan dalam budidaya sayuran. Kontaminasi cacingan dapat terjadi terutama pada sayuran yang menjalar di permukaan tanah atau ketinggiaannya dekat dengan tanah. Penelitian yang akan dilakukan adalah penelitian analitik dengan desain penelitian cross sectional (potong melintang). Sampel penelitian ini berupa sayuran yang terdiri dari selada, daun bawang, kol, bayam, dan sawi sebanyak 50 sampel yang di ambil dari pasar tradisional dan pasar modern di Kota Medan. Dari hasil penelitian ini didapatkan bahwa hasil STH positif tertinggi di pasar tradisional sebanyak 10 sayuran atau $(40 \%)$ dan hasil STH positif terendah di pasar modern sebanyak 3 sayuran atau (25\%). Berdasarkan hasil penelitian ini dapat disimpulkan bahwa ada perbedaan STH dari sayuran yang dijual di pasar tradisional dengan pasar modern yang dibuktikan dengan nilai $p$ pada perbandingan ini adalah $\mathrm{p}=0,035$, jadi terdapat perbedaan kontaminasi Soil Transmitted Helmints antara pasar tradisional dan pasar modern.
\end{abstract}

\section{Kata Kunci: Soil Transmitted Helmints, Pasar Tradisional, Pasar Modern}

\section{PENDAHULUAN}

SoilTransmitted Helminths adalah dengan telur ataupun larva parasit itu sekelompok cacing parasit (kelas sendiri yang berkembang di tanah yang Nematoda) yang dapat menyebabkan lembab yang terdapat di negara yang infeksi pada manusia melalui kontak beriklim tropis maupun Jurnal Ilmu Kedokteran Dan Kesehatan, Volume 6, Nomor 1, Januari 2019 
subtropics(Ashika, et al., 2014). Infeksi Soil Transmitted Helmiths (STH) masih merupakan masalah di banyak daerah di dunia, terutama di negara yang sedang berkembang dengan sanitasi lingkungan dan kebersihan diri yang sangat kurang. Terdapat lebih dari 1,5 milyar orang atau $2,4 \%$ dari populasi dunia terinfeksi kecacingan yang ditularkan melalui tanah(Gunawan, 2014). Angka kejadian tertinggi penyakit ini terdapat pada kawasan sub-Sahara Afrika, Amerika, China, dan Asia Timur. Berdasarkan laporan hasil survey prevalensi penyakit kecacingan pada 10 provinsi, didapatkan angka kecacingan nasional adalah 30,95\%. Berdasarkan data departemen Parasitologi FKUI mulai 2002-2009 angka kejadian penyakit kecacingan berbeda-beda di setiap daerah di Indonesia (Hastono dan Sabri, 2013). Jumlah infeksi STH sangat banyak di Asia Tenggara termasuk Indonesia, letak geografis Indonesia yang beriklim tropis sesuai untuk perkembangan parasit. Geographical Information System (GIS) menyatakan distribusi STH di Indonesia mencakup seluruh pulau yang ada di Indonesia, dimana prevalensi tertinggi terdapat di Papua dan Sumatera Utara dengan prevalensi antara $50 \%$ hingga 80\%(Hutasoit, 2015).

STH yang paling sering menginfeksi manusia adalah Ascaris lumbricoides, Trichuris trichiura, Ancylostoma duodenale dan Necator americanus. Ascaris lumbricoides merupakan salah satu infeksi yang paling sering menginfeksi pada manusia sekitar 49,02\%, Ancylostomiasis menginfeksi 1,2 milliar di seluruh dunia, sedangkan Trichuris Trichiura diperkirakan mencapai $30 \%$ atau sebanyak 900 juta orang terinfeksi1. Distribusi STH di Indonesia mencakup seluruh pulau yang ada di Indonesia, prevalensi $A$. lumbrocides sebanyak $60-90 \%$ dan cacing tambang (hookworm) sebanyak 40\%.

Prevalensi infeksi cacing usus pada 10 propinsi tahun 2004, Sumatera Utara menduduki peringkat ketiga $(60,4 \%)$ dalam hal penyakit cacingan. Prevalensi di Sumatera Utara diperkirakan yaitu, Ascaris 50 - 79,9\%, Trichuariasis 80 $100 \%$, dan infeksi Hookworms 50 79,9\%. Di kota Medan ditemukan prevalensi Ascariasis 29,2\%,
Trichuariasis 6,3\%. Angka kontaminasi STH di pasar tradisional yaitu sebesar $85.0 \%$, dengan proporsi Strongyloides $35,0 \%$, larva rhabditiform Strongyloides $30 \%$, telur Hookworm 15\%, dan Toxocara 5\%. Pada pasar modern angka kontaminasi STHyaitu sebesar 90\%, dengan proporsi Strongyloides 35\%, telur Hookworm 20\% dan telur Toxocara 5\%(Jusuf, et al., 2013).

Berdasarkan penelitan yang pernah di lakukan di pasar tradisional dan pasar modern di kota Medan, ditemukan angka kontaminasi STHpada sayuran selada yang cukup tinggi. Angka kontaminasi STHdi pasar tradisional yaitu sebesar $85,0 \%$, dengan proporsi Strongyloides $35,0 \%$, larva rhabditiform Strongyloides $30 \%$, telur hookworm 15\%, dan toxocara $5 \%$. Pada pasar modern angka kontaminasi STHyaitu sebesar, 90\%, dengan proporsi Strongyloides (35\%), free living Strongyloides $(30 \%)$, telur hookworm, 20\%, dan telur toxocara, 5\%(Jusuf, et al., 2013).

Berdasarkan penelitian sebelumnya didapatkan hasil STH positif pada 32 dari 44 sayuran selada dari pasar tradisional di Kota Padang dengan persentase $73 \%$. Tiga dari 5 sayuran selada dari pasar modern di Kota Padang dinyatakan positif dengan persentase $40 \%$. Jenis STH terbanyak yang peneliti temukan pada penelitian ini adalah telur Ascaris sp (79\%), larva Trichostrongylus orientalis $(16 \%)$ dan telur cacing tambang (5\%)(Hastono dan Sabri, 2013). Secara keseluruhan, sayur selada, timun, kubis, daun perai, dan daun bawang dari pasar tradisional dan pasar modern di kota Medanmenunjukkan hasil positif kontaminasi parasit yaitu masing-masing 57 sampel positif $(75.0 \%)$ dan 19 sampel positif $(25.0 \%)$ (Notoadmojo, 2012). Tingginya prevalensi ini sangat didukung oleh keadaan alam yang cocok bagi siklus hidup cacing seperti daerah beriklim panas dan lembab, hygiene perorangan dan sanitasi lingkungan yang rendah, khususnya di lingkungan pertanian sayur. Rendahnya tingkat sanitasi pribadi mempengaruhi angka kejadian penyakit ini, seperti tidak mencuci tangan sebelum makan dan setelah buang air besar (BAB), tidak 
menjaga kebersihan dan memotong kuku.

Salah satu sumber penularannya adalah air dan lumpur yang digunakan dalam budidaya sayuran. Kontaminasi cacingan dapat terjadi terutama pada sayuran yang menjalar di permukaan tanah atau ketinggiaannya dekat dengan tanah. Kebiasaan makan sayuran mentah ini, sudah mentradisi di Indonesia sehingga kelihatannya sulit diubah. Namun, dari segi keamanannya, lalapan mentah beresiko terkontaminasi pestisida atau telur cacing. Selain itu para petani seringkali menggunakan pupuk organik berupa humus atau kotoran ternak (bahkan kotoran manusia) untuk meningkatkan kesuburan tanah.

Daerah yang tidak memiliki sanitasi yang baik dan kelembapan tinggi yang mana sangat baik untuk berkembangnya telur STHmenjadi bentuk infektif. Infeksi ditularkan oleh telur yang ada di kotoran manusia, yang mencemari tanah dimana adanya kebiasaan para petani sayur menggunakan tinja sebagai pupuk yang mana hal tersebut akan menyebabkan tercemarnya sayuran oleh STH yang ada pada pupuk yang terbuat dari kotoran dan melekatnya telur pada sayuran. Bila dalam proses pengolahan dan pencucian sayuran tidak baik, telur cacing kemungkinan masih melekat pada sayuran dan tertelan saat sayuran dikonsumsi. Meski sejauh ini belum dilaporkan adanya kasus orang yang keracunan atau meninggal gara-gara mengkonsumsi lalapan mentah, tapi tak ada salahnya kita lebih memerhatikan keamanan pangan yang dikonsumsi.

Berdasarkan hasil survei awal dengan cara menanyakan kepada pedagang sayuran tentang daerah asal sayuran yang di jual didapatkan suatu kesimpulan bahwa sayuran yang di jual di pasar tradisional di kota medan berasal dari daerah perkebunan yaitu Berastagi. Kondisi perkebunan yang jauh dari sumber air dan tempat $B A B$, membuat petani sering sekali $B A B$ ditengah perkebunan, sehingga tanah tercemar oleh feses yang mengandung telur cacing. STH akan berkembang biak dengan baik pada tanah gembur dan lembab. Sayuran dapat ditanam pada berbagai jenis tanah, namun pertumbuhan yang baik akan diperoleh bila ditanam pada tanah gembur, lembab dan mengandung cukup bahan organik. Kondisi ini yang membuat banyak nya sayuran yang terkontaminasi STH.

Kontaminasi sayuran oleh telur nematoda usus diduga berasal dari air penyiram yang digunakan oleh para petani perkebunan sayur untuk menyiram sayuran, karena air penyiram berasal dari kolam yang juga dipergunakan untuk buang air besar oleh masyarakat sekitar. Setelah sayuran dipanen, keesokan harinya kemudian diangkut menuju kota/pasar untuk dijual, supaya tidak layu, sayuran disiram dengan air selokan ataupun air sungai yang berada ditempat terdekat dengan perkebunan sayur tersebut. Air selokan atau air sungai yang digunakan dikhawatirkan mengandung telur nematoda usus sehingga dapat mengkontaminasi sayuran pada saat proses penyiraman dan menempel pada sayur-sayuran. Oleh karena itu, jika terdapat orang yang terinfeksi cacingan maka telur cacing yang berada pada kolam tersebut dapat mengalir menuju sungai sehingga dapat mencemari air sungai. Apabila air sungai tersebut digunakan untuk mencuci dan menyiram sayur-sayuran setelah dipanen dikhawatirkan telur nematoda usus dapat menempel pada sayuran (Ravinchandran, 2015).

Di kota Medan banyak sekali masyarakat yang mengkonsumsi sayuran dalam keadaan mentah terutama sayuran lalapan pada restaurant cepat saji, restaurant jepang, restaurant korea, seafood, ayam penyet dan pecel lele. Salah satu sayuran yang banyak di konsumsi masyarakat Indonesia khusunya kota Medan adalah salada, dimana salada termasuk sayuran yang berkontak langsung dengan tanah. Terbukti dari selada yang mudah ditemukan pada makanan asing seperti salad, hot dog, ramen, hamburger, sandwich. Makanan Indonesia juga banyak menggunakan selada seperti gado-gado, lalapan nasi goreng, dan lalapan pecel lele. Berbeda dengan sayuran lain, selada tidak pernah dimasak karena setelah dimasak rasanya menjadi berubah. Hal ini memungkinkan telur STH dengan mudah masuk ke 
dalam tubuh karena sayuran yang dikonsumsi tidak dicuci bersih. Saat memasak sayuran pun jarang sekali masyarakat mencuci sayuran dengan bersih sebelum di masak, hal ini tentu saja membuat STH yang ada pada sayuran dapat masuk ke tubuh saat sayuran di makan. Masyarakat di kota medan cenderung lebih banyak membeli sayuran pada pasar tradisional dari pada pasar modern.

Dari hasil pengamatan peneliti, pedagang sayuran di pasar tradisional di kota Medan sering kali mengabaikan hygiene dari sayuran yang di jual nya. Kebanyakan sayuran yang di jual di pasar tradisional dalam keadaan kotor, berlumpur, bertanah dan diletakan sembarangan. Berbeda dengan pasar modern, hygiene sayuran di pasar modern sangat baik, sayuran di pasar modern bersih, dibungkus plastik dan tersusun rapi. Berdasarkan uraian diatas bahwa telur cacing dapat ditemukan di sayuran yang terkontaminasi oleh STH, oleh karena itu peneliti tertarik untuk mengetahui perbedaan STH pada sayuran di pasar modern dan pasar tradisional di kota Medan tahun 2016.

\section{METODE PENELITIAN}

Penelitian yang akan dilakukan adalah penelitian analitik dengan desain penelitian cross sectional (potong melintang) yaitu dengan melakukan pengamatan terhadap sayur - sayuran yang terkontaminasi oleh telur cacing.Desain cross sectional adalah suatu desain penelitian dimana pengumpulan data atau variabel yang akan diteliti berupa variabel dependen dan independen, dinilai secara simultan pada satu saat yang dalam penelitian (Sostroasmoro dan Isamel, 2014). Alasan peneliti menggunakan desain cross sectional adalah mudah dilaksanakan, sederhana, ekonomis dalam hal waktu, dan hasil dapat diperoleh dengan cepat dan dalam waktu bersamaan dapat dikumpulkan variabel yang banyak, baik variabel independen maupun variabel dependen. Penelitian ini dilaksanakan di pasar modern dan pasar tradisional Medan, pada bulan Febuari tahun 2017.

Populasi

keseluruhan karakteristiknya akan didugag. Populasi yang akan digunakan pada penelitian ini adalah seluruh pedagang sayuran yang ada di pasar modern dan pasar tradisional di Medan.

Sampel adalah sebagian objek yang akan diteliti dan dianggap mewakili seluruh populasi. Pengambilan sampel pada penelitian ini menggunakan metodePurposive Sampling yang artinyasuatu cara pengambilan sampel secara sengaja sesuai dengan persyaratan sampel yang diperlukan. Dengan menggunakan purposive sampling, diharapkan kriteria sampel yang diambil benar-benar sesuai dengan penelitian yang akan dilakukan 10 .

Teknik pengambilan sampel merupakan cara peneliti untuk mengumpulkan sampel yang akan dilakukan dalam penelitian. Teknik pengambilan sampel pertama kali dilakukan survei awal, setelah mendapatkan populasi untuk dijadikan objek penelitian.Sampel yang digunakan dalam penelitian ini menggunakan sayuran yang terdapat di 5 pasar modern, yaitu: Hypermart, Carefour, Maju Bersama, Suzuya, Berastagi supermarket dan 5 pasar tradisional, yaitu: pasar johor, pasar setiabudi, pasar simpang limun, pasar juanda, pasar jamin ginting. Sampel dipilih dengan cara mengambil 5 jenis sayuran yaitu sawi, kol, daun bawang, selada, dan bayam. Selanjutnya sampel akan diperiksa menggunakan mikroskop di ruang laboratorium mikrobiologiFK UISU. Pemeriksaan dilakukan dengan menemukan telur cacing yang terdapat disayuran.

Prosedur pengumpulan data dilakukan dengan cara:

a. Merendam sayur ke dalam larutan $\mathrm{NaOH} 0,2 \%$ sebanyak 1 liter dalam beker glass selama 30 menit.

b. Sayur dikeluarkan dari larutan.

c. Air rendaman disaring dan dimasukan ke dalam beker glass yang lainnya.

d. Air yang ada di permukaan dibuang, sedangkan yang ada di bawah diambil dengan pipet volume 10$15 \mathrm{ml}$.

e. Air endapan di centrifuge dengan kecepatan 1500/rpm selama 5 menit. 
f. Air yang mengendap diambil menggunakan pipet pasteur dan diteteskan di atas objek glass.

g. Kaca objek ditutup dengan kaca penutup, kemudian diperiksa dibawah mikroskop dengan pembesaran 40 kali (Jusuf, et al., 2013).

Pada penelitian ini menggunakan Analisa Univariat dan Bivariat.Analisa Univariat merupakan analisis yang melibatkan satu variabel atau per variabel. Dimana variabel dalam penelitian ini adalah sayuran yang terinfeksi STH. Analisa Univariat ini bertujuan untuk menjelaskan atau mendeskripsikan karakteristik masingmasing variabel yang diteliti. Analisa univariat berfungsi untuk meringkas kumpulan data hasil pengukuran sedemikian rupa sehingga kumpulan data tersebut berubah menjadi informasi yang berguna.

Analisa Bivariat merupakan analisis yang melibatkan dua variabel. Tujuan dari analisa bivariat ini untuk mengetahui perbedaan sayuran yang terinfeksi STH di pasar tradisional dan pasar modern. Analisa data dengan menggunakan uji Wilcoxon. Uji Wilcoxon adalah suatu pengujian yang digunakan untuk mengetahui ada tidaknya perbedaan antara dua sampel dependen yang berpasangan atau berkaitan dan digunakan sebagai alternatif pengganti uji Paired Sample $T$ Test jika data tidak berdistribusi normal. Uji Wilcoxon digunakan untuk menganalisis hasil-hasil pengamatan yang berpasangan dari dua data apakah berbeda atau tidak.

Lokasi bagi penelitian ini merupakan pasar tradisional dan pasar modern yang menjual sayur selada, kol, daun bawang, bayam dan sawi di pasar tradisional dan pasar modern di kota Medan. Terdapat 5 pasar tradisional yaitu pasar johor, pasar setiabudi, pasar simpang limun, pasar juanda, pasar jamin ginting dan 5 pasar modern yaitu carefour, hypermart, maju bersama, berastagi supermarket, suzuya. Sedangkan Lokasi pemeriksaan sampel dilakukan di laboratorium mikrobiologi FK UISU yang berada di jalan Sisingamangaraja no. 2A.

Sampel penelitian ini adalah sayur selada, kol, daun bawang, bayam dan sawi di pasar tradisional dan pasar modern di kota Medan. Sebanyak50 sampel sayur telah dilakukan pemeriksaan untuk penelitian ini yaitu 25 sayur dari 5 pasar tradisional, setiap pasar tradisional masing-masing diambil 5 jenis sayuran dan diambil sampel 25 sayur dari 5 pasar modern, setiap pasar modern masing-masing diambil 5 jenis sayuran.

\section{HASIL PENELITIAN}

Tabel 4.1 Distribusi Frekuensi Jenis Sayuran

\begin{tabular}{ccc}
\hline Sayur & Frekuensi & $\begin{array}{c}\text { Persentase } \\
(\%)\end{array}$ \\
\hline Sawi & 10 & 20,0 \\
Selada & 10 & 20,0 \\
Daun & 10 & 20,0 \\
Bawang & 10 & 20,0 \\
Kol & 10 & 20,0 \\
Bayam & 50 & 100,0 \\
\hline Total &
\end{tabular}

Berdasarkan tabel 4.1 diatas dapat dilihat dari 50 sampel sayuranterdapat jumlah sawi, selada, daun

bawang, kol, bayam masing-masing

berjumlah 10 sayur (20,0\%).

Tabel 4.2 Distribusi Frekuensi Sayuran BerdasarkanJenis Pasar

\begin{tabular}{ccc}
\hline Jenis Pasar & Frekuensi & $\begin{array}{c}\text { Persentasi } \\
(\%)\end{array}$ \\
\hline $\begin{array}{c}\text { Pasar } \\
\text { Tradisional } \\
\text { Pasar } \\
\text { Modern }\end{array}$ & 25 & 50,0 \\
\hline Total & 25 & 50,0 \\
\hline Berdasarkan & tabel & 4.2 diatas
\end{tabular}

didapatkan bahwa jumlah sayurpasar tradisional dan pasar modern masingmasing berjumlah 25 sayuran $(50,0 \%)$.

Tabel 4.3 Distribusi Frekuensi Sayuran Berdasarkan STH

\begin{tabular}{ccc}
\hline STH & Frekuensi & $\begin{array}{c}\text { Persentasi } \\
(\%)\end{array}$ \\
\hline Negatif & 37 & 74,0 \\
Positif & 13 & 26,0 \\
\hline Total & 50 & 100,0 \\
\hline
\end{tabular}

Dari hasil pemeriksaan sampel didapati hasil STH terbanyak yaitu 
negatif sebanyak 37 sayuran $(74,0 \%)$

dan yang paling sedikit yaitu positif

sebanyak 13 sayuran $(24,0 \%)$.

Tabel 4.4 Distribusi Jenis Parasit Berdasarkan Jenis Sayuran

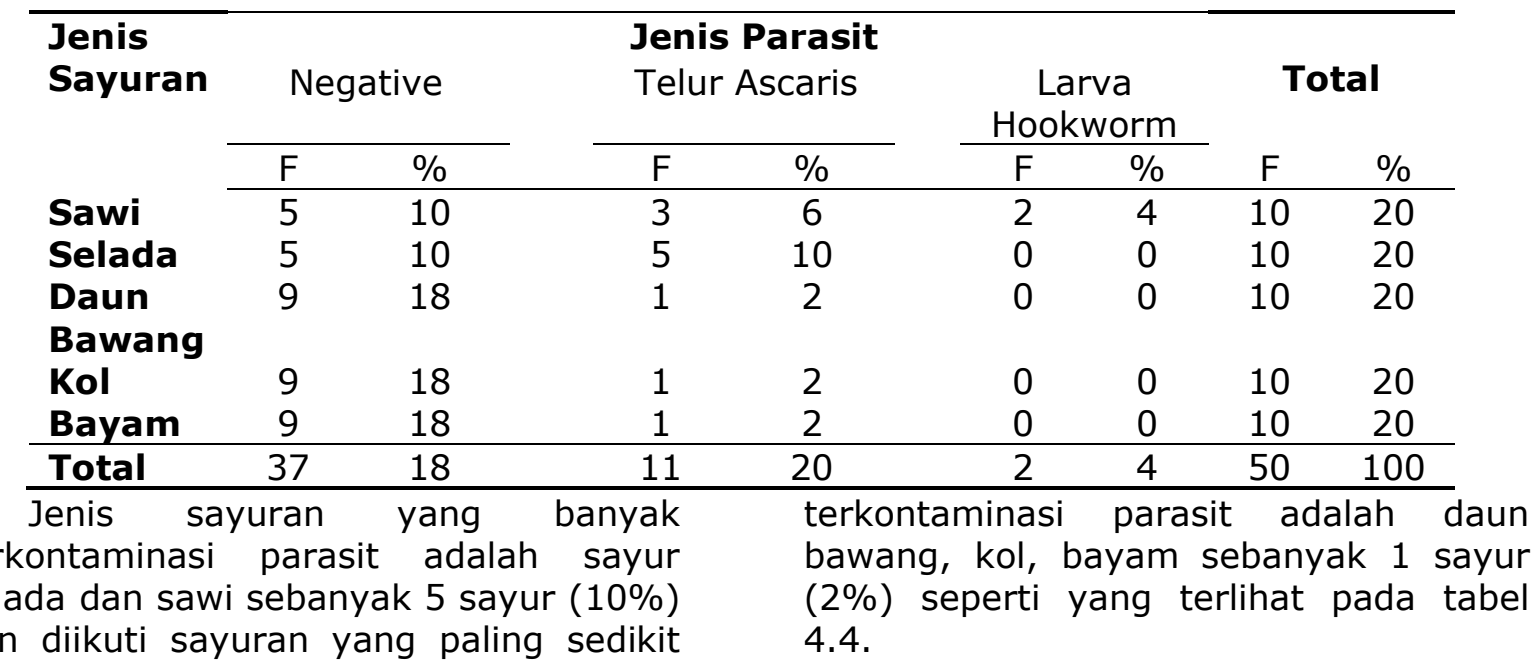

Tabel 4.5 Distribusi Jenis Parasit Berdasarkan Jenis Pasar

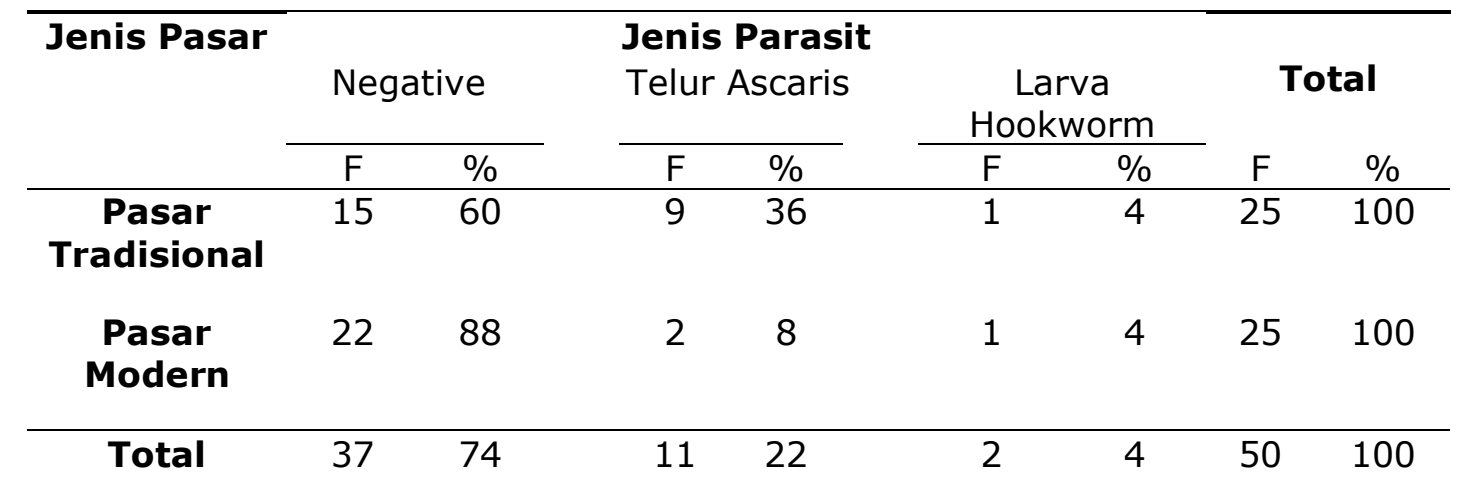

Pada tabel 4.5 bisa dilihat bahwa jenis parasit yang paling banyak terdapat di pasar tradisional adalah telur ascaris sebanyak 9 telur (36\%) dan

jenis parasit paling sedikit terdapat di pasar tradisional dan pasar modern adalah larva hookworm masing-masing sebanyak 1 larva (4\%).

Tabel 4.6 Distribusi STH Berdasarkan Jenis Pasar

\begin{tabular}{|c|c|c|c|c|c|c|}
\hline \multirow[t]{2}{*}{ Jenis Pasar } & \multicolumn{2}{|c|}{ STH Negatif } & \multicolumn{2}{|c|}{ STH Positif } & \multicolumn{2}{|c|}{ Total } \\
\hline & $\mathrm{F}$ & $\%$ & $\mathrm{~F}$ & $\%$ & $\mathrm{~F}$ & $\%$ \\
\hline Tradisional & 15 & 60 & 10 & 40 & 25 & 100 \\
\hline Modern & 22 & 88 & 3 & 12 & 25 & 100 \\
\hline Total & 37 & 74 & 13 & 26 & 50 & 100 \\
\hline
\end{tabular}

Dari hasil pemeriksaan sampel didapati hasil STH positif terbanyak dipasar tradisional yaitu sebanyak 10 sayuran atau $(40 \%)$ sedangkan pada pasar modern hanya3 sayuran (12\%), sebagaimana yang tercantum pada tabel 4.6. Untuk mengetahui data terdistribusi normal atau tidak maka dilakukan uji normalitas. Setelah dilakukan uji normalitas menggunakan metode Shapiro-Wilk maka didapatkan hasil signifikansi 0,001. Apabila nilai signifikansi $<0,05$ maka data tidak terdistribusi normal. Maka selanjutnya data akan di analisa menggunakan uji Wilcoxon. 
Tabel 4.7 Hasil Analisa Bivariat

\begin{tabular}{|c|c|c|c|c|c|}
\hline \multirow{3}{*}{ Jenis Pasar } & \multirow{2}{*}{\multicolumn{2}{|c|}{$\begin{array}{l}\text { STH } \\
\text { Negatif }\end{array}$}} & \multirow{2}{*}{\multicolumn{2}{|c|}{$\begin{array}{c}\text { STH } \\
\text { Positif }\end{array}$}} & \multirow{3}{*}{ Nilai p } \\
\hline & & & & & \\
\hline & $\mathrm{F}$ & $\%$ & $\mathrm{~F}$ & $\%$ & \\
\hline Tradisional & 15 & 60,0 & 10 & 40,0 & 0,035 \\
\hline Modern & 22 & 88,0 & 3 & 12,0 & \\
\hline Total & 37 & 74,0 & 13 & 26,0 & \\
\hline
\end{tabular}

\begin{abstract}
Setelah dilakukan uji statistik dengan menggunakan uji Wilcoxonmenunjukkan bahwa terdapat adanya perbedaan yang signifikan antara STH di pasar tradisional dan pasar
\end{abstract}

\section{PEMBAHASAN}

Berdasarkan tabel 4.4 didapatkan bahwa jenis sayuran yang banyak terkontaminasi parasit adalah sayur selada dan sawi sebanyak 5 sayur (10\%) dan diikuti sayuran yang paling sedikit terkontaminasi adalah daun bawang, kol, bayam sebanyak 1 sayur (2\%). Hal ini sesuai dengan penelitian yang dilakukan Ravicandran (2015)menunjukkan hasil kontaminasi terbanyak pada pasar modern dan pasar tradisional yaitu sayur selada sebanyak 9 sayur (36\%). Begitu juga dengan penelitian Asihka (2014) dimana penelitian ini dilakukan pada selada. Pada sayuran selada yang dijual di pasar tradisional dengn proporsi sebesar $73 \%$ (32 sampel) dari 44 sampel penelitian positif terkontaminasi dan pada pasar modern 40\% (2 sampel) dari 5 sampel penelitian positif terkontaminasi. Sayuran hijau seperti selada memiliki permukaan yang tidak rata sehingga lebih memudahkan melekatnya telur parasit walaupun sudah dicuci dengan air. Sayuran dengan permukaan yang lembut ataupun licin seperti daun bawang dan daun prei mempunyai proporsi kontaminasi yang rendah. Ini bisa disebabkan oleh sayur yang diperoleh dalam keadaan fisik kotor dan tidak diberinya perlakuan mencuci sebelum dijual ke pasar sehingga kemungkinan untuk terjadinya kontaminasi cukup besar.

Menurut Karuppiah (2010) dalam Ravichandran (2015) Faktor yang mempengaruhi keberadaan STH pada sayur seperti penggunaan pupuk organik modern dengan nilai probabilitas $(p)=0,035$. Hal itu dapat dilihat pada tabel 4.7, Jika nilai $\mathrm{p}<0,05$ maka Ho ditolak.

yang berasal dari ternak hewan sebagai media penyuburan sayuran. Sama halnya seperti pada manusia, jika kotoran ternak tersebut mengandung telur STH, maka dengan mudahnya telur STH yang ada di dalam kotoran ternak yang digunakan sebagai pupuk akan berpindah ke sayur yang kontak langsung dengan tanah. Berdasarkan pengamatan, sayur di pasar modern diletakkan di lemari berpendingin. Keberadaan STH pada sayur dari pasar modern mungkin dapat disebabkan karena teknik pencucian sayur yang tidak tepat.

Menurut Syahputri (2015) hal ini dapat disebabkan oleh sayur selada, kol, daun bawang dan daun prei adalah tanaman yang menjalar atau dekat dengan tanah sehingga mudah terjadinya kontaminasi parasit, dan didukung oleh struktur sayur yang berlapis - lapis dan berlekuk - lekuk sehingga memungkinkan telur/larva cacing menetap di dalamnya. Adapun saat dilakukan pengambilan sampel, pada pasar tradisional pedagang umumnya menjual dagangannya menggunakan terpal yang diletakkan dekat dengan tanah sehingga terjadinya kontaminasi menjadi lebih besar sedangkan pada pasar modern sendiri sayuran dijual dalam keadaan sudah terplastik dan diletakkan di mesin pendingin sayuran sesuai dengan jenis sayuran itu sendiri.

Dari tabel 4.5 diatas dapat disimpulkan bahwa jenis parasit yang paling banyak terdapat di pasar 
tradisional adalah telur ascaris sebanyak 9 telur (36\%) dan jenis parasite paling sedikit terdapat di pasar tradisional dan pasar modern adalah larva hookworm masing-masing sebanyak 1 larva (4\%). Hal ini sejalan dengan penelitian Asihka (2014) dimana jenis STH terbanyak yang peneliti temukan pada penelitian ini adalah telur Ascaris sp (79\%), larva Trichostrongylus orientalis (16\%) dan telur cacing tambang (5\%). Hal ini di dukung teori WHO (2016) Infeksi Soil Transmitted Helminths ini merupakan infeksi paling umum di daerah tropis terutama pada masyarakat ekonomi lemah yang tinggal di daerah kumuh. Infeksi ini dapat terjadi bila manusia tertelan telur/larva infeksius (A.lumbricoides dan T.trichiura) atau dengan penetrasi bentuk larva filariform (larva hookworm) yang berada di tanah.Menurut Soedarto (2011) keberadan dan penyebaran suatu parasit di suatu daerah tergantung pada berbagai hal, yaitu adanya hospes yang peka, dan terdapatnya lingkungan yang sesuai bagi kehidupan parasit. Faktor sosial ekonomi hospes, terutama manusia, sangat mempengaruhi penyebaran parasit. Daerah pertanian, peternakan, kebiasaan menggunakan tinja untuk pupuk, kebersihan lingkungan, higiene perorangan yang buruk, dan kemiskinan merupakan faktor - faktor yang meningkatkan penyebaran penyakti parasit.

Dari tabel 4.6diatas dapat disimpulkan bahwa hasil STH negatif terbanyak di pasar modern yaitu sebanyak 22 sayuran $(88,0 \%)$ dan hasil STH positif terbanyak di pasar tradisional sebanyak 10 sayuran atau (40,0\%). Hal ini sejalan dengan penelitian Ravichandran (2015) menunjukkan hasil positif kontaminan parasit terbanyak pada pasar tradisional sebanyak $75 \%$ sedangkan hasil negatif terbanyak pada pasar modern sebanyak $8,1 \%$. Menurut Haq (2014), hasil tampaknya menunjukkan bahwa salah satu sebab penting dari infeksi parasit adalah karena konsumsi sayuran mentah dan kotor. Semua sayuran harus dicuci sebelum memadai akan konsumsi dan mana mungkin, dekontaminan harus dimasukkan dalam air cuci. Potensial lainnya kontaminasi seperti panen prosedur, lingkungan terkontaminasi selama penanganan, transportasi dan penyimpanan, atau langsung kontaminasi dari individu yang terlibat dalam produksi dan pengolahan produk juga tidak diselidiki.

Hal ini sesuai dengan Karuppiah (2010), yang mengatakan kebiasaan kesemua pengusaha pasar tradisional dengan pasar modern yang ada mengamalkan perlakuan mencuci sayur sebelum ia dijual menunjukkan hasil negatif bagi kontaminasi parasit. Faktor ini yang mempengaruhi keberadaan STH pada sayur seperti penggunaan pupuk organik yang berasal dari ternak hewan sebagai media penyuburan sayuran. Sama halnya seperti pada manusia, jika kotoran ternak tersebut mengandung telur STH, maka dengan mudahnya telur STH yang ada di dalam kotoran ternak yang digunakan sebagai pupuk akan berpindah ke sayur yang kontak langsung dengan tanah. Berdasarkan pengamatan, sayur di pasar modern diletakkan di lemari berpendingin. Keberadaan STH pada sayur dari pasar modern mungkin dapat disebabkan karena teknik pencucian sayur yang tidak tepat.

Dari tabel 4.7diatas dapat disimpulkan bahwa hasil STH negatif terbanyak di pasar modern yaitu sebanyak 22 sayuran $(88,0 \%)$ dan hasil STH positif terbanyak di pasar tradisional sebanyak 10 sayuran atau $(40,0 \%)$. Perbedaan STH di pasar tradisional dan pasar modern melalui uji statistik dengan menggunakan uji Wilcoxonmenunjukkan bahwa terdapat adanya perbedaan antara STH di pasar tradisional dan pasar modern dengan nilai probabilitas $(p)=0,035$. Jika nilai $p$ $<0,05$ maka Ho ditolak sedangkan $\mathrm{Ha}$ diterima. Hal ini sejalan dengan penelitian Ravichandran (2015) menunjukkan hasil positif kontaminan parasit terbanyak pada pasar tradisional sebanyak $75 \%$ sedangkan hasil negatif terbanyak pada pasar modern sebanyak $8,1 \%$ dan ada perbedaan yang signifikan STH di pasar modern dan pasar tradisional dengan nilai signifikansi $p=0,011$. Hal ini kemungkinan disebabkan karena kurangnya perhatian dari pengusaha sayur dari pasar tradisional dalam higienitas sayuran 
yang dijualnya. Pedagang sayuran di pasar tradisional di kota Medan sering kali mengabaikan hygiene dari sayuran yang di jual nya. Kebanyakan sayuran yang di jual di pasar tradisional dalam keadaan kotor, berlumpur, bertanah dan diletakan sembarangan. Berbeda dengan pasar modern, hygiene sayuran di pasar modern sangat baik, sayuran di pasar modern bersih, dibungkus plastik dan tersusun rapi. Keterbatasan pada penelitian ini adalah jumlah sampel yang kurang banyak untuk membandingkan kontaminasi STH antara sayuran di pasar tradisional dan pasar modern, selain itu jumlah pasar tradisional dan pasar modern yang menjadi tempat pengambilan sampel kurang banyak. Begitupun dengan biaya dan waktu, keterbatasan biaya dan waktu untuk penelitian ini menyebabkan penelitian ini masih memiliki kekurangan.

\section{KESIMPULAN}

Berdasarkan hasil yang didapatkan dari penelitian ini perbedaan STH pada sayuran di pasar tradisional dan pasar modern, dapat ditarik kesimpulan sebagai berikut:

a. Pada pasar tradisional didapati hasil STH positif sebanyak 10 sayuran $(40 \%)$, sedangkan STH negatif sebanyak 15 sayuran (60\%).

b. Pada pasar modern didapati hasil positif sebanyak 3 sayuran, sedangkan hasil negatif sebanyak 22 sayuran $(44 \%)$.

c. Terdapat perbedaan Soil Transmitted Helminths pada sayuran di pasar tradisional dan pasar modern dengan nilai $p=0,035$.

\section{DAFTAR PUSTAKA}

Asihka, V., Nurhayati., Gayatri., (2014). Distribusi Frekuensi Soil Transmitted HIminth Pada Sayuran Selada yang Dijual di Pasar Tradisional dan Pasar
Modern di Kota Padang. Diakses pada tanggal05 November 2015 dari http://jurnal.fk.unand.ac.id

Gunawan, C.A. (2014). Soil Transmitted Helminth. Jakarta: Interna Publishing.

Hastono, S.P., Sabri, L., (2013). Statistik Kesehatan. Jakarta: PT. Raja Grafindo Persada.

Hutasoit, H.P. (2015). Pencemaran Soil Transmitted Helminths Pada Sayuran di Pasar Tradisional dan Pasar Modern di kota Medan Bagian Kota. Medan: Universitas Sumatera Utara.

Jusuf, A., Ruslan., Seloma, M., (2013). Gambaran Parasit Soil Transmitted Helminths dan Tingkat Pengetahuan, Sikap Serta Tindakan Petani Sayur di Desa Waiheru Kecamatan Baguala Kota Ambon. Ambon: Universitas Hasanudin.

Notoatmojo, S., (2012). Metodologi Penelitian Kesehatan. Jakarta: Rineka Cipta.

Ravichandran, N.A.P. (2015). Perbandingan Pencemaran Soil Transmitted Helminth Pada Sayuran di Pasar Tradisional dan Pasar Modern di Medan Bagian Barat kota Medan. Medan: Universitas Sumatera Utara.

Sastroasmoro, S., Ismael, S., (2014). Dasar-dasar Metodologi Penelitian Klinis. Jakarta: Sagung Seto.

Suryani, D. (2012). Hubungan Perilaku Mencuci Dengan Kontaminasi Telur Nematoda Usus Pada Sayuran Kubis Pedagang Pecel Lele di Kelurahan Warungboto kota Yogyakarta.Diakses pada tanggal $05 \quad$ November2016 darihttp://download.portalgaruda. org/article

WHO.(2016). Soil Transmitted Helminth Infection.Diakses pada tanggal 04 Desember 2016 dari http://who.int/mediacentre/sth 